\title{
Potential of Postharvest Coatings to Maintain Freshness of Red-Fleshed Pitaya (Hylocereus costaricensis)
}

\author{
Nur Azlin Razali ${ }^{1,2}$, Steven A. Sargent ${ }^{1, * \mathbb{D}}$, Charles A. Sims ${ }^{3}$, Jeffrey K. Brecht ${ }^{1}$, Adrian D. Berry ${ }^{1}$ \\ and Guiwen Cheng ${ }^{4}$ (D) \\ 1 Horticultural Sciences Department, University of Florida/IFAS, Gainesville, FL 32611, USA; \\ nurazlin@mardi.gov.my (N.A.R.); jkbrecht@ufl.edu (J.K.B.); adberry@ufl.edu (A.D.B.) \\ 2 Horticultural Research Centre, Malaysian Agricultural Research and Development Institute (MARDI), \\ Serdang 43400, Selangor, Malaysia \\ 3 Food Science and Human Nutrition Department, University of Florida/IFAS, Gainesville, FL 32611, USA; \\ csims@ufl.edu \\ 4 JBT Corporation, 400 Fairway Avenue, Lakeland, FL 33801, USA; Alvin.Cheng@JBTC.COM \\ * Correspondence: sasa@ufl.edu; Tel.: +1-352-273-4780
}

Citation: Razali, N.A.; Sargent, S.A.; Sims, C.A.; Brecht, J.K.; Berry, A.D.; Cheng, G. Potential of Postharvest Coatings to Maintain Freshness of Red-Fleshed Pitaya (Hylocereus costaricensis). Agriculture 2021, 11, 892. https://doi.org/10.3390/ agriculture11090892

Academic Editor: John M. Fielke

Received: 18 August 2021

Accepted: 13 September 2021

Published: 16 September 2021

Publisher's Note: MDPI stays neutral with regard to jurisdictional claims in published maps and institutional affiliations.

Copyright: (C) 2021 by the authors. Licensee MDPI, Basel, Switzerland. This article is an open access article distributed under the terms and conditions of the Creative Commons Attribution (CC BY) license (https:/ / creativecommons.org/licenses/by/ $4.0 /)$.

\begin{abstract}
Pitaya is a non-climacteric fruit that has white or red flesh with numerous small, black seeds. It has a high moisture content; however, water loss during handling and storage negatively affects the fresh weight, firmness and appearance of the fruit, decreasing market value. Application of compatible postharvest coatings has been shown to benefit postharvest quality of many crops. The objective of this study was to evaluate the effect of two commercial coatings on weight loss and quality of pitaya during storage. Pitaya fruit were commercially harvested and sorted for uniformity of size and freedom from defects. Fruit were briefly immersed in either a vegetable oil-based coating (VOC; Sta-Fresh ${ }^{\circledR}$ 2981) or a carnauba-based coating (CC; Endura-Fresh ${ }^{\mathrm{TM}} 6100$ ) according to manufacturer's recommendations. Fruit immersed in tap water served as a control. Fruit were fan-dried at room temperature for $20 \mathrm{~min}$, then stored at $7{ }^{\circ} \mathrm{C}$ with $85 \%$ relative humidity $(\mathrm{RH})$ and evaluated for selected physical quality parameters each 5 days during 20 days. After each evaluation, fruit were peeled and frozen for later analysis of soluble solids content (SSC), total titratable acidity (TTA); on day 15 fresh samples were evaluated by an untrained consumer sensory panel. CC prevented exocarp shriveling for 15 days of storage, compared to uncoated pitaya (16.3\% area affected); shriveling in VOC was intermediate and not significantly different from the other treatments. Mesocarp firmness remained constant throughout 15 days of storage regardless of treatment. Fruit exocarp $\mathrm{h}^{*}$ angle increased slightly by day 20, becoming slightly less red, and there were no negative treatment effects for the other quality factors measured: SSC $(11.33 \%)$, TTA $(0.25 \%)$, weight loss $(5.5 \%)$ or sensory evaluations (appearance, flavor, texture, firmness, and juiciness). After 20 days storage, appearance for fruit from all treatments was rated unacceptable due to development of anthracnose lesions. It was concluded that both CC and VOC maintained quality of pitaya for 15 days at $7^{\circ} \mathrm{C}$ and $85 \% \mathrm{RH}$ by delaying exocarp shriveling.
\end{abstract}

Keywords: dragon fruit; pitahaya; climbing cactus; storage life; lipid-based coating; carnauba coating

\section{Introduction}

Pitaya originates from Central America and belongs to the genus Hylocereus of the botanical family Cactaceae. It is a climbing plant with vigorous vines and the scarlet fruit have white or red flesh with numerous small black seeds. Fruit diameter ranges from 10 to $15 \mathrm{~cm}$ and weight is between 250 to $600 \mathrm{~g}$. Since pitaya is a non-climacteric fruit, it should be harvested near full ripeness when the quality is acceptable. However, without proper handling, the quality of pitaya picked at optimum harvest maturity for sensory appreciation decreases rapidly during storage. 
As a cactus, pitaya fruit preserve high water content on the plant by means of the thickness of the exocarp, the presence of scales, and the high mucilage content in the mesocarp [1]. However, once harvested Nerd et al. [2] reported that pitayas (H. undatus) stored at $65-75 \%$ relative humidity $(\mathrm{RH})$ had weight loss of $4.2 \%$ after 1 week at $20{ }^{\circ} \mathrm{C}$ and $5.8 \%$ water loss after 3 weeks at $6{ }^{\circ} \mathrm{C}$. Water loss affects the fresh weight, firmness, and appearance of the fruit as well as the market price. Market price for fresh pitaya in the United States is high; in March 2021, wholesale price for a 4.5-kg package was \$50 [3]. The high demand and high prices have created interest on the part of growers in subtropical producing regions like Homestead, Florida, to trial this unique crop.

Coating technology has been developed to improve the storage and shelf life of fruits and vegetables. Postharvest coatings can have beneficial effects on fruit quality such as enhancing visual quality, suppressing ripening and shrinkage, retarding water loss, and increasing resistance to fruit decay [4-6]. Postharvest coatings for produce are generally formulated to provide an optimum water vapor permeability for water loss control and regulate respiratory gas permeability. By lowering the internal oxygen concentration and raising the internal carbon dioxide concentration, a beneficial modified atmosphere is created [7]. Optimum internal atmospheres range from $1-15 \%$ for $\mathrm{CO}_{2}$ and from $2-10 \%$ for $\mathrm{O}_{2}$, depending on the fruit or vegetable being coated, and extending postharvest life beyond that achieved without the coating [8,9]. The use of natural ingredients for postharvest coating for fruits and vegetables is in high demand due to the low impact on the environment and human health as well as disease biocontrol [10]. Commercial coatings are typically applied by immersion or spraying. Immersion of pitaya fruit in chitosan solution showed potential to reduce perishability and extend its shelf life [11]. Ali et al. [12] reported that pitaya treated with chitosan coating maintained acceptable fruit quality for up to 28 days at $10{ }^{\circ} \mathrm{C}$ without any off-flavors. Pitaya coated with a combination of chitosan and oleic acid also delayed the rotting incidence caused by fungi, maintained skin firmness, and minimized weight loss [13]. A coating containing propolis (the natural "glue" produced by honeybees) also helped slow the ripening process while increasing the biosynthesis of nutritional components in pitaya [14]. Vegetable oil and carnauba wax are lipid-based coatings that have been reported to have beneficial effects on fresh produce such as Chinese pear (Pyrus bretschmeideri Rehd.) [15], tomato (Solanum lycopersicum) [16] and pitaya $[12,17,18]$. These coatings are stable at ambient temperatures, emulsify, and do not compromise the quality of fresh fruits and vegetables. Vegetable oils (soybean, corn, peanut, linseed, and cottonseed) are widely used as coatings to delay ripening and maintain fruit quality [15]. Carnauba wax comes from the carnauba palm, grown in northeastern Brazil [19]. Machado [20] reported that carnauba-based waxes preserved the freshness of citrus fruit by reducing mass loss and peel dehydration, and by retaining green color. However, each lipid-based coating has different behavior moisture barrier properties due to the nature of the hydrophobic components [21].

The objective of this study was to determine how application of commercial vegetable oil-based and carnauba-based coatings affects the postharvest quality of red-fleshed pitaya (Hylocereus costaricensis) during simulated commercial storage.

\section{Materials and Methods}

\subsection{Plant Materials}

Pitaya fruit (cv. 'Lisa') were harvested at commercial maturity (about 30 days after anthesis) by a grower in Homestead, FL in two subsequent years (20 November 2015 and 27 October 2016). Shortly after harvest the fruit were transported under refrigeration to the Postharvest Horticulture Laboratory at the University of Florida in Gainesville. Following overnight storage at $15^{\circ} \mathrm{C}$ and $85 \% \mathrm{RH}$, the ovoid-shaped fruit were sorted for uniformity of size (average $=230 \mathrm{~g}$ ), freedom from defects and decay, and cleaned with soft, dry wipes to remove surface particulates. Fruit were randomized into three treatment groups ( $n=40$ fruit): VOC (vegetable oil-based coating, Sta-Fresh ${ }^{\circledR} 2981$, JBT Corporation, Lakeland, FL, USA) [22], CC (carnauba-based coating, Endura-Fresh ${ }^{\mathrm{TM}}$ 6100, 
JBT Corporation, Lakeland, FL, USA) [23], and control (tap water). Each fruit was immersed in either CC or VOC coating, prepared according to the label, or water at room temperature $\left(24{ }^{\circ} \mathrm{C}\right)$ for $30 \mathrm{~s}$ and this was done gently to prevent damage to the scales. From each treatment, samples were divided into two groups for quality evaluation $(n=20)$ and sensory evaluation $(n=20)$. Fruit were air-dried using a fan at room temperature for about $20 \mathrm{~min}$, placed on single-layer trays and stored at $7^{\circ} \mathrm{C}$ and $85 \% \mathrm{RH}$ for 20 days.

\subsection{Quality Analyses}

Fruit $(n=4)$ from each treatment were removed from storage every 5 days for evaluation of shriveling and incidence of decay, and overall appearance ratings, and measurement of weight loss, external color and firmness. Severity of shriveling and yellow lesions were rated according to the total surface area of each fruit that was affected, as $0 \%$ (no trace), $<15 \%$ (slightly affected), 16-25\% (moderately affected), 25-50\% (badly affected) and $>50 \%$ (severely affected). For overall acceptability rating, fruit were rated as 5 (excellent), 4 (good), 3 (acceptable), 2 (poor) and 1 (very poor). Fruit with more than $50 \%$ shriveling or decay symptoms and rated as poor or very poor for overall acceptability were considered unacceptable for sale and consumption.

\subsection{External Color and Weight Loss}

External color was determined using a colorimeter (model CR-400, Konica Minolta Sensing, Tokyo, Japan) with D65 illuminant, obtaining CIE L*, $\mathrm{a}^{*}$, and $\mathrm{b}^{*}$ values; the $\mathrm{a}^{*}$ and $b^{*}$ values were converted into hue angle $\left(h^{*}\right)$ and chroma value $\left(C^{*}\right)$ as described by McGuire [24]. At each measurement time the colorimeter was calibrated using the white calibration plate provided with the instrument. External color measurements were taken on the flat area between the calyx and the stem end of the fruit. Fruit weight loss (\% fresh weight basis) was calculated as the difference between fruit weight at harvest and fruit weight after 5, 10, 15 and 20 days of storage (Equation (1)).

$$
Y=\frac{W_{i}-W_{t}}{W_{i}}(100)
$$

where,

$$
\begin{aligned}
& Y: \text { Weight loss, } \%, \\
& W_{i}: \text { initial weight, } g, \\
& W_{t}: \text { storage weight, } g .
\end{aligned}
$$

\subsection{Mesocarp Firmness}

Mesocarp firmness was measured in 2016 after fruit were conditioned to room temperature for about $1 \mathrm{~h}$, at which time the fruit was sliced longitudinally into three sections of equal thickness. The center section was laid on the flat plate of a texture analyzer (model TA.HDPlus, Texture Technologies Corp, Hamilton, MA, USA) and two measurements were made per slice and averaged. An 11-mm diameter, convex probe and crosshead speed of $2 \mathrm{~mm} \cdot \mathrm{s}^{-1}$ with a $50-\mathrm{N}$ load cell was used to determine the bioyield point and is expressed in Newtons $(\mathrm{N})(n=8)$.

\subsection{SSC, TTA and SSC:TTA Ratio}

After each evaluation, fruit were peeled and the fruit mesocarp tissues were frozen $\left(-20^{\circ} \mathrm{C}\right)$ for later analysis of soluble solids content (SSC) and total titratable acidity (TTA). Each sample was later blended then centrifuged (Thermo Scientific Lynx 4000 Sorvall, Osterode am Harz, Germany) for $20 \mathrm{~min}$ at $19,319 \times g$ at $4{ }^{\circ} \mathrm{C}$. The juice was filtered through four layers of cheesecloth and the filtrate was collected. Soluble solids content was quantified by placing a drop of juice on a digital refractometer (model r2i300, Reichert Technologies, Depew, NY, USA); TTA was determined with an automatic titrator (model 905 Titrando; Metrohm Ion Analysis, Herisau, Switzerland). For TTA, 3 mL of juice diluted 
with $15 \mathrm{~mL}$ of water was titrated with $0.1 \mathrm{M} \mathrm{NaOH}$ to $\mathrm{pH} 8.2$ and reported as percent malic acid.

\subsection{Sensory Evaluation}

Consumer testing was conducted in the Sensory Laboratory, Food Science \& Human Nutrition Department, University of Florida after 15 days storage. The objective of this test was to determine fruit acceptance and any differences between fruit coated with VOC, CC or control. Fruit $(n=20)$ from each treatment were sliced into wedges and served on individual plates (the peel still intact to evaluate the external appearance). Each plate consisted of two wedges for each treatment. Fruit were prepared immediately prior to serving to the panelists at room temperature.

Panelists $(n=71)$ rated each sample for 'like' or 'dislike' of external and internal appearance, overall acceptability, flavor, and texture using 9-point hedonic scales ( 1 = dislike extremely and $9=$ like extremely); firmness and juiciness were rated using 5-point "Just About Right" scales ( $1=$ much too soft/dry and $5=$ much too firm/juicy). Unsalted crackers and water were given as a palate cleanser between samples. All orders of presentation were presented to panelists approximately and equal number of times. Additionally, ranking was also used to determine fruit preference. A questionnaire consisting of those six sensory characteristics was prepared and panelist responses were analyzed using Compusense Software (Guelph, ON, Canada).

\subsection{Statistical Analysis}

The same experiment was conducted once in each of two consecutive years using a completely randomized design. An analysis of variance (ANOVA) test was performed on each variable using the SAS statistical package (SAS Institute, 2002-2012). For quality measurements, the mean values of four replicate samples were compared using Duncan Multiple Range test $(p \leq 0.05)$. Sensory analysis was conducted only the second year; ANOVA was performed using a randomized complete block design (RCBD) with panelists as blocks. Tukey's HSD was used to compare the mean values of samples.

\section{Results}

\subsection{Quality Ratings}

Statistical analysis showed there was no significant interaction between year and coating treatment (data not shown), therefore data for both years were merged for this report. Fruit appearance is very important in relation to consumer acceptability. Fruit that appear fresh and free from defects and decay will attract consumers as well as command a higher market price. Subjective ratings were utilized for overall appearance (scale and stem appearance; peel color) and fruit surface area showing shrivel symptoms and disease were estimated. After 15 days of storage pitaya fruit coated with either CC or VOC had no or slight shriveling ( $0 \%$ and $5.0 \%$ of surface area, respectively), significantly $(p \leq 0.05)$ less than that for uncoated pitaya (16.3\%) and considered moderate (Table 1). At day 20,50\% of uncoated pitaya fruit surface showed severe shriveling (Figure 1), while fruit coated with CC or VOC exhibited only $20 \%$ or $25 \%$ moderate shriveling, respectively. Although both coatings significantly reduced visible shriveling as compared to control fruit, data analysis revealed that there was no effect of coating on weight loss during storage: the overall means at each evaluation increased notably up to $5.5 \%$ weight loss after 20 days of storage (Table 1). 
Table 1. Weight loss (\%), shriveling (\% surface area), anthracnose fruit rot (\% surface area) and overall acceptability ratings (scale 1-5) for whole, coated and uncoated pitaya fruit during 20 days storage at $7{ }^{\circ} \mathrm{C}$.

\begin{tabular}{|c|c|c|c|c|c|}
\hline Storage (d) & Coating & Weight Loss $(\%)^{z}$ & Shriveling (\%) & Anthracnose Fruit Rot (\%) & Overall Acceptability Rating \\
\hline \multirow{3}{*}{0} & VOC & $0.0 \mathrm{a}$ & $0.0 \mathrm{a}^{\mathrm{y}}$ & $0.0 \mathrm{a}$ & $5.0 \mathrm{a}$ \\
\hline & $\mathrm{CC}$ & $0.0 \mathrm{a}$ & $0.0 \mathrm{a}$ & $0.0 \mathrm{a}$ & $5.0 \mathrm{a}$ \\
\hline & Control & $0.0 \mathrm{a}$ & $0.0 \mathrm{a}$ & $0.0 \mathrm{a}$ & $5.0 \mathrm{a}$ \\
\hline \multirow{3}{*}{5} & VOC & $1.56 \mathrm{ab}$ & $0.0 \mathrm{a}$ & $0.0 \mathrm{a}$ & $5.0 \mathrm{a}$ \\
\hline & $\mathrm{CC}$ & $1.11 \mathrm{~b}$ & $0.0 \mathrm{a}$ & $0.0 \mathrm{a}$ & $5.0 \mathrm{a}$ \\
\hline & Control & $1.68 \mathrm{a}$ & $0.0 \mathrm{a}$ & $0.0 \mathrm{a}$ & $5.0 \mathrm{a}$ \\
\hline \multirow{3}{*}{10} & VOC & $2.97 \mathrm{a}$ & $3.8 \mathrm{a}$ & $0.0 \mathrm{a}$ & $5.0 \mathrm{a}$ \\
\hline & $\mathrm{CC}$ & $2.64 \mathrm{a}$ & $0.0 \mathrm{a}$ & $0.0 \mathrm{a}$ & $5.0 \mathrm{a}$ \\
\hline & Control & $2.95 \mathrm{a}$ & $7.5 \mathrm{a}$ & $0.0 \mathrm{a}$ & $5.0 \mathrm{a}$ \\
\hline \multirow{3}{*}{15} & VOC & $4.10 \mathrm{a}$ & $5.0 \mathrm{ab}$ & $5.3 \mathrm{a}$ & $3.8 \mathrm{a}$ \\
\hline & $\mathrm{CC}$ & $3.86 \mathrm{a}$ & $0.0 \mathrm{~b}$ & $2.8 \mathrm{a}$ & $4.0 \mathrm{a}$ \\
\hline & Control & $4.76 \mathrm{a}$ & $16.3 \mathrm{a}$ & $10.0 \mathrm{a}$ & $3.8 \mathrm{a}$ \\
\hline \multirow{3}{*}{20} & VOC & $5.45 \mathrm{a}$ & $25.0 \mathrm{~b}$ & $17.5 \mathrm{a}$ & $2.8 \mathrm{a}$ \\
\hline & $\mathrm{CC}$ & $5.25 \mathrm{a}$ & $20.0 \mathrm{~b}$ & $15.0 \mathrm{a}$ & $2.8 \mathrm{a}$ \\
\hline & Control & $5.8 \mathrm{a}$ & $50.0 \mathrm{a}$ & $25.0 \mathrm{a}$ & $2.5 \mathrm{a}$ \\
\hline
\end{tabular}

${ }^{z}$ Fruit $(n=4)$ surface area (\%) showing shriveling or decay; $0 \%=$ none, $<15 \%=$ slight, $15-49 \%=$ moderate, $>50 \%=$ severe. Overall acceptability ratings based on a 5-point rating from 1 = very poor, $3=$ limit of acceptability, $5=$ excellent. ${ }^{y}$ Means in each column with the same letter and by storage day are not significantly different according to Duncan's Multiple Range test at $p \leq 0.05$. Data represents the mean $(n=4)$.

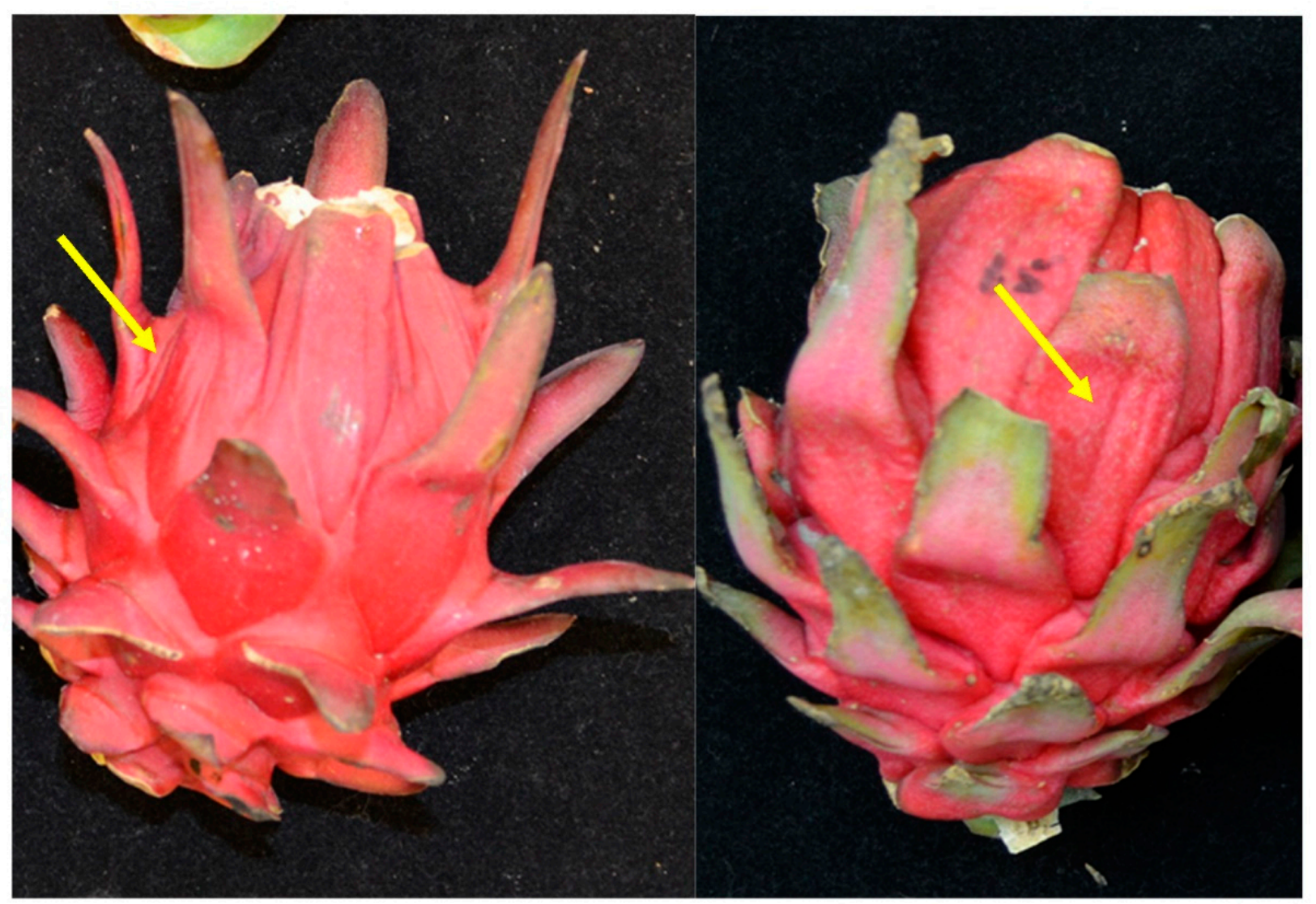

Figure 1. Scale shriveling in uncoated pitaya fruit after 20 days storage at $7^{\circ} \mathrm{C}$.

Yellow lesions began to appear by Day 15, at which time severity ranged from $2 \%$ to $10 \%$; by day 20 lesions increased to $15.5 \%$ to $20.0 \%$ (Table 1 ). These were diagnosed as Colletotrichum gloeosporioides, also known as anthracnose fruit rot (Plant Diagnostic Center 
at the University of Florida). Pitaya coated with CC was scored as acceptable on day 15 $(2.8 \%)$; however, by day 20 fruit from all treatments had surface blemishes $>50 \%$ and were thus rated as unacceptable (acceptability ratings $<3.0$ ).

\subsection{External Color}

Coatings did not negatively affect external color characteristics of pitaya during the 20 days of storage. There were no significant changes in $\mathrm{L}^{*}$ value (mean $=34.49$ or $\mathrm{C}^{*}$ value (mean $=34.01) ; h^{*}$ angle increased slightly from 17.12 to 23.08 , becoming slightly less red (Table 2).

Table 2. Main effects and interactions for external color of whole, coated and uncoated pitaya fruit during 20 days storage at $7{ }^{\circ} \mathrm{C}$.

\begin{tabular}{cccc}
\hline Main Effect & L* Value $^{*}$ & Hue* Angle $^{*}$ & Chroma* Value \\
\hline Coating & & & \\
VOC & $34.56 \mathrm{a}^{\mathrm{z}}$ & $16.44 \mathrm{a}$ & $34.54 \mathrm{a}$ \\
CC & $34.88 \mathrm{a}$ & $18.94 \mathrm{a}$ & $33.10 \mathrm{a}$ \\
Control & $34.03 \mathrm{a}$ & $17.30 \mathrm{a}$ & $34.39 \mathrm{a}$ \\
Storage Period & & $17.12 \mathrm{~b}$ & $31.12 \mathrm{c}$ \\
Day 0 & $35.52 \mathrm{a}$ & $16.28 \mathrm{~b}$ & $33.96 \mathrm{abc}$ \\
Day 5 & $33.06 \mathrm{~b}$ & $15.53 \mathrm{~b}$ & $35.55 \mathrm{ab}$ \\
Day 10 & $33.25 \mathrm{~b}$ & $15.60 \mathrm{~b}$ & $36.45 \mathrm{a}$ \\
Day 15 & $34.88 \mathrm{a}$ & $23.08 \mathrm{a}$ & $33.06 \mathrm{bc}$ \\
Day 20 & $35.70 \mathrm{a}$ & $\mathrm{ns}$ & $\mathrm{ns}$ \\
Interactions & $\mathrm{ns}$ & $\mathrm{y}$ & \\
Coating $\times$ Storage & & & \\
\hline
\end{tabular}

${ }^{z}$ Means in each column within the Main Effect with the same letter are not significantly different according to Duncan's Multiple Range test at $p \leq 0.05 .{ }^{\mathrm{y}} \mathrm{ns}=$ not statistically different at $p \leq 0.05$ from ANOVA.

\subsection{Mesocarp Firmness}

Mesocarp firmness, as determined by bioyield point, remained constant $($ mean $=8.17 \mathrm{~N})$ during 15 days of storage, regardless of treatment. It was not possible to determine firmness at day 20 because of increased decay which reduced replication by as much as $50 \%$ (data not shown).

\subsection{SSC, TTA and SSC:TTA Ratio}

Main effects for coating showed no significant differences for soluble solids content (SSC), total titratable acidity (TTA) or sugar:acid ratio (SSC:TTA). Therefore, only overall means are presented for each main effect: SSC $=11.64 \%$, TTA $=0.38 \%$, SSC:TTA $=35.97$ ) (Table 3). However, by day 20 of storage, TTA decreased to less than half the initial value, from $0.59 \%$ to $0.25 \%$, irrespective of treatment. Because SSC remained constant during storage, the SSC:TTA ratio doubled from the initial value of 22.03 to 46.26 . The sugar-acid ratio is an important indicator for the flavor quality of the fruit by reflecting the relative contents of sugar and acids.

\subsection{Sensory Evaluation}

The sensory evaluation was conducted on day 15 of storage to avoid the unmarketable appearance that was observed with extended storage at day 20. The evaluation consisted of 71 panelists of which $57.8 \%$ were female. The panelist demographics were Caucasian $(54.9 \%)$, Asian (23.9\%), Hispanic (11.3\%), African American (4.2\%), and Other (5.6\%). Median age was 25 years.

There were no statistical differences among treatments for any of the sensory attributes evaluated, indicating that the presence of the coating did not change the sensory attributes of pitaya fruit during storage (Table 4). External and internal appearance was rated an average of 6.68 and 6.95, respectively; although internal appearance for control fruit was rated statistically lower than the coated treatments, it was not considered commercially 
important. Overall acceptability was rated 6.5. In relation to the 1-9 rating scale used, the means for these attributes can be described as panelists liking the fruit moderately. Sensory data showed no significant differences between treatments for either texture $($ mean $=6.65)$ or firmness (mean $=2.94$ ) of the fruit. Panelists disliked the firmness moderately, noting that the seeds were too large and crunchy. Panelists also found no difference in flavor $($ mean $=6.29)$, juiciness $($ mean $=2.94)$, or ranking preference between the treatments. Other comments provided by the panelists mentioned that pitaya, coated or uncoated, tasted similar, with mild, bland, or earthy flavor. Some thought the texture was similar to that of a pomegranate or kiwi fruit.

Table 3. Main effects and interactions for composition of mesocarp tissue from coated and uncoated pitaya fruit after 20 days storage at $7{ }^{\circ} \mathrm{C}$.

\begin{tabular}{cccc}
\hline Main Effect & SSC (\%) & $\begin{array}{c}\text { TTA } \\
(\%, \text { Malic Acid Basis) }\end{array}$ & SSC:TTA Ratio \\
\hline Coating & & & \\
VOC & $11.78 \mathrm{a} \mathrm{z}^{\mathrm{z}}$ & $0.38 \mathrm{a}$ & $35.51 \mathrm{a}$ \\
CC & $11.46 \mathrm{a}$ & $0.38 \mathrm{a}$ & $35.77 \mathrm{a}$ \\
Control & $11.70 \mathrm{a}$ & $0.38 \mathrm{a}$ & $35.81 \mathrm{a}$ \\
Storage Period & & & $22.03 \mathrm{~d}$ \\
Day 0 & $11.71 \mathrm{ab}$ & $0.59 \mathrm{a}$ & $29.17 \mathrm{c}$ \\
Day 5 & $11.32 \mathrm{~b}$ & $0.41 \mathrm{~b}$ & $33.77 \mathrm{~b}$ \\
Day 10 & $11.87 \mathrm{ab}$ & $0.37 \mathrm{~b}$ & $47.37 \mathrm{a}$ \\
Day 15 & $11.99 \mathrm{a}$ & $0.26 \mathrm{c}$ & $\mathrm{ns}$ \\
Day 20 & $11.33 \mathrm{~b}$ & $0.25 \mathrm{c}$ & $\mathrm{n}$ \\
Interactions & $\mathrm{ns}$ & $\mathrm{ns}$ & $\mathrm{y}$ \\
Coating $\times$ Storage & $\mathrm{n}$ & &
\end{tabular}

\footnotetext{
${ }^{\mathrm{z}}$ Means in each column within the Main Effect with the same letter are not significantly different according to Duncan's Multiple Range test at $p \leq 0.05$. ' $\mathrm{ns}=$ not statistically different at $p \leq 0.05$ from ANOVA.
}

Table 4. Sensory panel results for appearance, overall acceptability, texture, and flavor (9-point hedonic scale) and firmness and juiciness (5-point Just About Right Scale) of coated and uncoated pitaya fruit after 15 days storage at $7^{\circ} \mathrm{C}$.

\begin{tabular}{cccccccc}
\hline & \multicolumn{3}{c}{ 9-Point Hedonic Scale $\mathbf{z}$} & & \multicolumn{2}{c}{ 5-Point Just About Right (JAR) Scale } \\
\cline { 2 - 8 } Coating & $\begin{array}{c}\text { External } \\
\text { Appearance }\end{array}$ & $\begin{array}{c}\text { Internal } \\
\text { Appearance }\end{array}$ & $\begin{array}{c}\text { Overall } \\
\text { Acceptability }\end{array}$ & Texture & Flavor & Firmness & Juiciness \\
\hline VOC & $6.75 \mathrm{a}^{\mathrm{y}}$ & $7.06 \mathrm{a}$ & $6.65 \mathrm{a}$ & $6.77 \mathrm{a}$ & $6.41 \mathrm{a}$ & $2.93 \mathrm{a}$ & $3.01 \mathrm{a}$ \\
CC & $6.51 \mathrm{a}$ & $6.96 \mathrm{a}$ & $6.39 \mathrm{a}$ & $6.62 \mathrm{a}$ & $6.14 \mathrm{a}$ & $2.92 \mathrm{a}$ & $2.89 \mathrm{a}$ \\
Control & $6.77 \mathrm{a}$ & $6.83 \mathrm{a}$ & $6.46 \mathrm{a}$ & $6.56 \mathrm{a}$ & $6.32 \mathrm{a}$ & $2.97 \mathrm{a}$ & $\mathrm{n}$ \\
Significance & $\mathrm{ns}$ & $\mathrm{ns}$ & $\mathrm{ns}$ & $\mathrm{ns}$ & $\mathrm{ns}$ & $\mathrm{ns}$ & $\mathrm{ns}$ \\
\hline
\end{tabular}

${ }^{\mathrm{z}}$ A 9-point hedonic scale from 1 = dislike extremely, to $9=$ like extremely. A 5-point Just About Right (JAR) Scale from $1=$ much too soft/dry, to $5=$ much too firm/juicy. ${ }^{y}$ Means in each column with the same letter are not significantly different according to Tukey's HSD test at $p \leq 0.05 .{ }^{\mathrm{x}} \mathrm{ns}=$ not statistically different at $p \leq 0.05$ from ANOVA.

\section{Discussion}

Shriveling became apparent after 15 days of storage, at which time VOC- or CCcoated pitayas had $\leq 5 \%$ shriveling, about $1 / 3$ that for uncoated fruit (Table 1 ). Weight loss increased during storage but there was no interaction with coating treatment (Table 2). Mean moisture loss for all treatments after 15 days was $4.42 \%$, in close agreement with that reported by Nerd et al. (2) for pitaya stored under similar conditions. According to Wills et al. [25], just 5\% moisture loss can generate shrivel symptoms that affect the visual quality of fresh produce. Machado et al. [20] found that 'Ortanique' tangor citrus fruit (Citrus sinensis (L.) Osbeck $\times$ Citrus reticulata Blanco) treated with a carnauba-based coating had less weight loss (16\%) than uncoated control fruit (20\%) after 15 days of storage; however, those fruit were stored under ambient conditions that aggravated weight loss $\left(22{ }^{\circ} \mathrm{C}\right.$ and low RH of $60 \%$ ). Gum arabic, oleic acid and cinnamon essential oil applied to guava fruit (Psidium guajava) effectively reduced weight loss compared to uncoated fruit [26]. 
Fruit typically soften during storage [12]; in the present study uncoated fruit and VOC- and CC-coated fruit maintained the initial firmness for 15 days at $7^{\circ} \mathrm{C}$, which was confirmed by sensory panelists (Table 4). Other reports have noted positive effects of coatings. Ergun et al. [27] found that mamey sapote fruit (Pouteria sapote (Jacq.) H.E. Moore and Stearn) with carnauba coating were firmer than uncoated fruit after 9 days at $20{ }^{\circ} \mathrm{C}$; Ju et al. [15] had similar findings for Chinese pear coated with vegetable oil during storage for 6 months at $0^{\circ} \mathrm{C}$. Chitosan coating showed potential to retain pitaya fruit firmness during 28 days storage at $10{ }^{\circ} \mathrm{C}$ [28], in which the authors speculated that this coating may have formed a semipermeable film on the fruit surface. Coatings can reduce the transmissivity of fruit surfaces, thereby modifying the internal atmosphere and extending postharvest life by retarding respiration and maintaining firmness, among other benefits [11]. Storage under elevated concentrations of $\mathrm{CO}_{2}$ and/or low concentrations of $\mathrm{O}_{2}$ has been reported to retard softening by limiting the activity of cell wall degrading enzymes such as polygalacturonase and pectin methylesterase [29]. The potential effects of the coatings inducing a modified, internal atmosphere were not investigated in this study. Nunes et al. [30] reported an increase in firmness of uncoated strawberries (Fragaria $\times$ ananassa as) delays to cooling increased; an increase in firmness of uncoated blueberries (Vaccinium ashei Reade) was also determined [31]. In both of these studies, increased firmness was attributed to epidermal toughening due to water loss. In this present study, had latent infection been controlled, one or both of these coatings may have extended firmness to day 20.

The trend for lower severity of anthracnose on CC-coated fruit after 15 days of storage, indicated the potential of this coating to reduce anthracnose infection. This result was similar to that of Ali et al. [12], who reported that chitosan coating reduced the onset of anthracnose in pitaya stored at $10{ }^{\circ} \mathrm{C}$. There were no statistical differences in color values due to coating treatment. However, there were minimal changes during storage. External color, $\mathrm{L}^{*}$ showed no consistent pattern during storage, indicating neither lightening nor darkening (Table 2). $\mathrm{h}^{*}$ remained statistically constant for the first 15 days of storage before increasing on day 20, suggesting that the fruit became slightly less red in color in the final days of storage. In contrast, $C^{*}$ increased in color intensity for 15 days before decreasing on day 20 at the end of storage. These minor color changes occurred as overall appearance ratings decreased between days 15 and 20 of storage due to increased decay (Table 1). In a storage study on mango (Mangifera indica), a climacteric fruit, it was reported that CC reduced $L^{*}$, increased $C^{*}$, and resulted in higher $h^{*}$ compared with uncoated fruit, which might indicate that the coating delayed ripening, thus delaying color development [32]. The $\mathrm{L}^{*}$ value of the mango peel coated with guar gum incorporated into an alginate coating also decreased during storage at $12{ }^{\circ} \mathrm{C}$ for 4 weeks [33]. However, color of white prickly pear (Opuntia albicarpa) coated with chitosan was unchanged during 16 days of storage at $4{ }^{\circ} \mathrm{C}$ and $85 \%$ of relative humidity [34]. In the present study, the lack of significant effect of coating on external color implies that little modification of the internal atmosphere occurred during the 20-day storage period.

In this study, the presence of the coatings did not affect soluble solids content (SSC) or total titratable acidity (TTA). Another study on mamey sapote fruit coated with carnauba wax also showed no effect of the coating on SSC or $\mathrm{pH}$ [27]. The reduction of TTA during storage in this study was similar that from a study by Nerd et al. [2] who reported that pitaya fruit TTA declined during storage at $6^{\circ} \mathrm{C}$ for 21 days. The decrease in TTA during storage is typical of fruit crops and indicates that the acids (substrates of respiration) were metabolized to a greater extent than sugars as a consequence of normal respiration.

Application of coatings did not affect the sensory attributes of pitaya fruit. Similar results were reported for sensory evaluations of pears (Pyrus communis) and apples (Malus domesticus) coated with candelilla wax coating (a lipid-based coating); there were no significant differences in the sensory attributes measured between coated and uncoated fruit $[35,36]$. White or red ready-to-eat prickly pears coated with chitosan had higher 
sensory values (color, firmness, aroma, flavor, and overall acceptance) than those for uncoated fruit when assessed during 16 days of storage at $4{ }^{\circ} \mathrm{C}$ [34].

\section{Conclusions}

Pitaya fruit coated with VOC or CC had significantly less shriveling than uncoated fruit during 15 days at $7{ }^{\circ} \mathrm{C}(85 \% \mathrm{RH})$. Although these coatings did not reduce weight loss during storage, there was no negative effect on peel or mesocarp color, chemical composition or the sensory attributes tested. Development of latent decay lesions between 15 and 20 days of storage was the limiting factor for shelf life in this study, illustrating the importance of a vigorous preharvest program to minimize populations of decay microorganisms in the field. Future research should focus on testing other formulations of CC coatings and natural ingredient-based coatings that could provide greater moisture loss control while prolonging the storage life of pitaya fruit.

Author Contributions: Conceptualization, S.A.S., C.A.S. and J.K.B.; Data curation, N.A.R. and C.A.S.; Formal analysis, N.A.R.; Funding acquisition, S.A.S.; Investigation, N.A.R.; Methodology, N.A.R., A.D.B. and G.C.; Project administration, S.A.S. and J.K.B.; Software, C.A.S.; Supervision, A.D.B.; Writing—original draft, N.A.R.; Writing—review \& editing, N.A.R., S.A.S., C.A.S., J.K.B., A.D.B. and G.C. All authors have read and agreed to the published version of the manuscript.

Funding: This research received no external funding. Author Nur Azlin Razali thanks MARDI for the scholarship to pursue the Master of Science Program in Horticultural Sciences (University of Florida, Gainesville, FL, USA).

Data Availability Statement: Hylocereus costaricensis fruit were used in this study.

Acknowledgments: The authors express their appreciation to Reed Olszack, Louie Carricarte, Unity Groves, and Leo Schuck, Red Pitaya Growers, for their collaboration with harvest and fruit donation during this project.

Conflicts of Interest: The authors declare no conflict of interest. The funders had no role in the design of the study; in the collection, analyses, or interpretation of data; in the writing of the manuscript, or in the decision to publish the results.

\section{References}

1. Yahia, E.M. Pitahaya (pitaya) (Hylocereus spp.). In Postharvest Biology and Technology of Tropical and Subtropical Fruits: Mangosteen to White Sapote; Woodhead Publishing: Cambridge, UK, 2011; Volume 4, p. 263.

2. Nerd, A.; Gutman, F.; Mizrahi, Y. Ripening and postharvest behaviour of fruits of two Hylocereus species (Cactaceae). Postharvest Biol. Technol. 1999, 17, 39-45. [CrossRef]

3. National Agriculture Statistics Service, United States Department of Agriculture (MarketNews-Fruit and Vegetable): Washington, DC, USA. 2017. Available online: https://www.marketnews.usda.gov/mnp/fv-report-top-filters?locName=\&commAbr= DRAGON\&commName=DRAGON\%20FRUIT\%20(RED\%20PITAYA)\&className=FRUITS\&rowDisplayMax=25\&startIndex= 1\&navClass=FRUITS\&navType=byComm\&repType=termPriceDaily\&type=termPrice (accessed on 14 July 2021).

4. Amarante, C.; Banks, N.H. Postharvest physiology and quality of coated fruits and vegetables. Hortic. Rev. 2001, 26, 161-238.

5. Arowora, K.; Williams, J.; Adetunji, C.; Fawole, O.; Afolayan, S.; Olaleye, O.; Adetunji, J.; Ogundele, B. Effects of Aloe vera coatings on quality characteristics of oranges stored under cold storage. Greener J. Agric. Sci. 2013, 3, 39-47. [CrossRef]

6. Cheng, S.; Yu, Y.; Guo, J.; Chen, G.; Guo, M. Effect of 1-methylcyclopropene and chitosan treatment on the storage quality of jujube fruit and its related enzyme activities. Sci. Hortic. 2020, 265, 109281. [CrossRef]

7. Tokatlı, K.; Demirdöven, A. Effects of chitosan edible film coatings on the physicochemical and microbiological qualities of sweet cherry (Prunus avium L.). Sci. Hortic. 2020, 259, 108656. [CrossRef]

8. Del-Valle, V.; Hernández-Muñoz, P.; Guarda, A.; Galotto, M. Development of a cactus-mucilage edible coating (Opuntia ficus indica) and its application to extend strawberry (Fragaria ananassa) shelf-life. Food Chem. 2005, 91, 751-756. [CrossRef]

9. Hagenmaier, R.D. A comparison of ethane, ethylene and $\mathrm{CO} 2$ peel permeance for fruit with different coatings. Postharvest Biol. Technol. 2005, 37, 56-64. [CrossRef]

10. Salgado-Cruz, M.d.l.P.; Salgado-Cruz, J.; García-Hernández, A.B.; Calderón-Domínguez, G.; Gómez-Viquez, H.; Oliver-Espinoza, R.; Fernández-Martínez, M.C.; Yáñez-Fernández, J. Chitosan as a Coating for Biocontrol in Postharvest Products: A Bibliometric Review. Membranes 2021, 11, 421. [CrossRef] [PubMed]

11. Olivas, G.I.; Barbosa-Cánovas, G. Edible Films and Coatings for Fruits and Vegetables. In Edible Films and Coatings for Food Applications; Huber, K., Embuscado, M., Eds.; Springer: New York, NY, USA, 2009. [CrossRef] 
12. Ali, A.; Zahid, N.; Manickam, S.; Siddiqui, Y.; Alderson, P.G. Double layer coatings: A new technique for maintaining physicochemical characteristics and antioxidant properties of dragon fruit during storage. Food Bioprocess Technol. 2014, 7, $2366-2374$. [CrossRef]

13. Espinal-Hernández, P.; Colinas-León, M.T.; Ybarra-Moncada, M.C.; Méndez-Zúñiga, S.N.; Corrales-García, J. Postharvest effects of 1-mcp and chitosan/oleic acid coating in pitaya (Stenocereus griseus H.). J. Prof. Assoc. Cactus Dev. 2021, $23,43-57$.

14. Zahid, N.; Ali, A.; Siddiqui, Y.; Maqbool, M. Efficacy of ethanolic extract of propolis in maintaining postharvest quality of dragon fruit during storage. Postharvest Biol. Technol. 2013, 79, 69-72. [CrossRef]

15. Ju, Z.; Duan, Y.; Ju, Z. Plant oil emulsion modifies internal atmosphere, delays fruit ripening, and inhibits internal browning in Chinese pears. Postharvest Biol. Technol. 2000, 20, 243-250. [CrossRef]

16. Dávila-Aviña, J.E.; Villa-Rodríguez, J.A.; Villegas-Ochoa, M.A.; Tortoledo-Ortiz, O.; Olivas, G.I.; Ayala-Zavala, J.F.; GonzálezAguilar, G.A. Effect of edible coatings on bioactive compounds and antioxidant capacity of tomatoes at different maturity stages. J. Food Sci. Technol. 2014, 51, 2706-2712. [CrossRef]

17. Zhang, Y.; Han, J.H. Mechanical and thermal characteristics of pea starch films plasticized with monosaccharides and polyols. J. Food Sci. 2006, 71, 109-118. [CrossRef]

18. Hu, H.; Li, X.; Dong, C.; Chen, W. Effects of wax treatment on quality and postharvest physiology of pineapple fruit in cold storage. Afr. J. Biotechnol. 2011, 10, 7592-7603.

19. Puttalingamma, V. Edible coatings of carnauba wax-A novel method for preservation and extending longevity of fruits and vegetables-A review. Intel. J. Food Saf. 2014, 16, 1-5.

20. Machado, F.L.D.C.; Costa, J.M.C.; Batista, E.N. Application of carnauba-based wax maintains postharvest quality of 'Ortanique' tangor. Food Sci. Technol. 2012, 32, 261-268. [CrossRef]

21. Morillon, V.; Debeaufort, F.; Blond, G.; Capelle, M.; Voilley, A. Factors affecting the moisture permeability of lipid-based edible films: A review. Crit. Rev. Food Sci. Nutr. 2002, 42, 67-89. [CrossRef]

22. JBT Corp. Sta-Fresh $2981^{\mathrm{TM}}$ Postharvest coating for pineapples. In Technical Data Sheet; JBT FoodTech: Chicago, IL, USA, Undated; p. 1.

23. JBT Corp. Endura-Fresh $6100^{\mathrm{TM}}$ Post-Harvest Coating for Fruit. In Technical Data Sheet; JBT FoodTech: Chicago, IL, USA, Undated; p. 1.

24. McGuire, R.G. Reporting of objective color measurements. HortScience 1992, 27, 1254-1255. [CrossRef]

25. Wills, R.; McGlasson, B.; Graham, D.; Joyce, D. Postharvest, an Introduction to the Physiology and Handling of Fruit, Vegetables and Ornamentals, 5th ed.; CABI: Wallingford, UK, 2007.

26. Etemadipoor, R.; Mirzaalian Dastjerdi, A.; Ramezanian, A.; Ehteshami, S. Ameliorative effect of gum arabic, oleic acid and/or cinnamon essential oil on chilling injury and quality loss of guava fruit. Sci. Hortic. 2020, 266, 109255. [CrossRef]

27. Ergun, M.; Sargent, S.A.; Fox, A.J.; Crane, J.H.; Huber, D.J. Ripening and quality responses of mamey sapote fruit to postharvest wax and 1-methylcyclopropene treatments. Postharvest Biol. Technol. 2005, 36, 127-134. [CrossRef]

28. Ali, A.; Zahid, N.; Manickam, S.; Siddiqui, Y.; Alderson, P.G.; Maqbool, M. Effectiveness of submicron chitosan dispersions in controlling anthracnose and maintaining quality of dragon fruit. Postharvest Biol. Technol. 2013, 86, 147-153. [CrossRef]

29. Salunkhe, D.K.; Boun, H.R.; Reddy, N.R. Storage, Processing and Nutritional Quality of Fruits and Vegetables; Fresh Fruits and Vegetables; CRC Press Inc.: Boston, MA, USA, 1991; Volume 1.

30. Nunes, M.; Brecht, J.; Sargent, S.; Morais, A. Effects of delays to cooling and wrapping on strawberry quality (cv. Sweet Charlie). Food Control 1995, 6, 323-328. [CrossRef]

31. Paniagua, A.; East, A.; Hindmarsh, J.; Heyes, J. Moisture loss is the major cause of firmness change during postharvest storage of blueberry. Postharvest Biol. Technol. 2013, 79, 13-19. [CrossRef]

32. Dang, K.T.; Singh, Z.; Swinny, E.E. Edible coatings influence fruit ripening, quality, and aroma biosynthesis in mango fruit. J. Agric. Food Chem. 2008, 56, 1361-1370. [CrossRef] [PubMed]

33. Rastegar, S.; Atrash, S. Effect of alginate coating incorporated with Spirulina, Aloe vera and guar gum on physicochemical, respiration rate and color changes of mango fruits during cold storage. Food Meas. 2021, 15, 265-275. [CrossRef]

34. Ochoa-Velasco, C.E.; Guerrero-Beltrán, J.Á. Postharvest quality of peeled prickly pear fruit treated with acetic acid and chitosan. Postharvest Biol. Technol. 2014, 92, 139-145. [CrossRef]

35. Cruz, V.; Rojas, R.; Saucedo-Pompa, S.; Martínez, D.G.; Aguilera-Carbó, A.F.; Alvarez, O.B.; Rodríguez, R.; Ruiz, J.; Aguilar, C.N. Improvement of shelf life and sensory quality of pears using a specialized edible coating. J. Chem. 2015, 2015, 138707. [CrossRef]

36. Ochoa, E.; Saucedo-Pompa, S.; Rojas-Molina, R.; Garza, H.d.l.; Charles-Rodríguez, A.V.; Aguilar, C.N. Evaluation of a candelilla wax-based edible coating to prolong the shelf-life quality and safety of apples. Am. J. Agric. Biol. Sci. 2011, 6, 92-98. [CrossRef] 